\title{
BOSQUE DE ACANTOS JUNTO AL GUADALQUIVIR
}

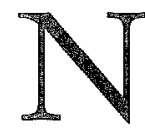

ACÍA la Escuela Superior de Arquitectura de Sevilla en el año 1960. Ahora, a punto de cumplir los cincuenta años, se publica una memoria precisa de datos, itinerarios pedagógicos, ensayos y experiencias académicas acumulados durante estos lustros en esa comunidad de alumnos y profesores que intercambian saberes, imaginan secuencias espaciales y se adiestran en el viejo oficio de «edificar la morada», y aquel recinto escolar consolidado sigue como $E s-$ cuela de oficios y saberes de la arquitectura.

El cronista, minucioso contador de lo acaecido, apoyado en una prosa que discurre por la mirada sensible del arquitecto y la velada metáfora del poeta, deja constancia y nos recuerda, con Maurice Blanchot, «... que todo lo que nos proponemos, todo lo que hemos adquirido, todo lo que somos, todo lo que se alce sobre la tierra y el cielo, retorna a lo insignificante».

También, que en estos lugares donde conviven o debería sobre-vivir pensamiento y oficio en el buen hacer de esta arcaica aventura, de «imaginar el cobijo» frente a la precaria indigencia de los tiempos, retorna a la costumbre de lo insignificante. Pero los itinerarios que nos conducen a la enseñanza de las nuevas trazas de estos recintos tan acendrados en la naturaleza de los grupos humanos, deben evolucionar por la vigencia del tiempo. Acotación que el autor decanta con destilada percepción en las trescientas páginas del libro que comentamos y lo hace con un discurso sereno, distante y afectivo, sin adjetivar pasajes ni recrudecer acontecimientos de la penuria, como digo, de los tiempos en que tuvieron lugar. 
Escrito bajo el epígrafe de Memoria, que me gustaría subtitular como «parábolas del vacío inocente de la enseñanza de la arquitecturas, en ese bosque de acantos plantado hace cincuenta años en las riberas del Guadalquivir.

Los diferentes apartados del libro ofrecen una meticulosa referencia de datos históricos, testimonio de los primeros acontecimientos escolares, evolución ideológica y cultural de la Escuela que con elegancia no caprichosa en su escritura ha sabido plasmar el profesor Juan Luis Trillo, testigo y superviviente como alumno primero, y activo catedrático después durante más de treinta años en los recintos universitarios de esta Escuela, en los campus de la Universidad de Sevilla.

La Escuela de Sevilla tiene su origen dentro de una planificación burocrático-administrativa que permitiera ampliar las enseñanzas técnicas en otras áreas localizadas más allá de las viejas escuelas de arquitectura de Madrid y Barcelona. La nueva Escuela surgía, como nos narra las páginas del libro, semitutelada por la Escuela de Madrid.

Nada de extraño por tanto que sus primeros lances proyectuales en relación con las orientaciones pedagógicas corroboren los postulados de la tentación lírica de la modernidad, saludando con entusiasmo aquellos proyectos arquitectónicos que defienden la primacía de lo «emotivo» sobre lo «racional», pese a tantos rasgos que anunciaban, por aquellos años, la belleza de la dictadura del ángulo recto, y que darían continuidad a las enseñanzas del proyecto de la arquitectura, dentro de aquel circulo de intereses que administraba una pedagogía mitificadora de la subjetividad profesional, uniforme y compacta, sometida al primitivismo que lastraban aún sectores de la cultura española.

No obstante, nos viene a señalar el autor, aparecían en los tránsitos a los nuevos testimonios orales y escritos de la Escuela sevillana expresiones, sin duda borrosas, de una enseñanza del proyecto alternativa. Estas primeras páginas de la breve historia de la Escuela, se suceden como lineales proverbios de la forma y el espacio en el buen arte de construir la arquitectura, y de manera colateral aparecía la crítica, por entonces solo enunciada, de la lógica de la mercancía contra los sentimientos.

Las conquistas de la revolución industrial, junto a los ideales tutelados por aquel Movimiento Moderno en Arquitectura 
(MMA), se identificaban con el siglo Xx; los tiempos del arquitecto deberían estar atentos a los peligros de los flujos demográficos y a su concentración en los arrabales de unas ciudades entumecidas. En este sentido la Escuela en la ciudad de Sevilla, provincia de patrimonios acotados, sería un buen adarve para otear y contrarrestar la dialéctica de la forma y los contenidos, los valores de la tradición y vanguardia, sociedad agraria y emancipación industrial, de unos programas ideales mitificados en otras latitudes y heridos ya por la esclusa del tiempo. Los postulados de la ciudad industrial resonaban como ecos tardíos en la vieja ciudad, según los cuales «la arquitectura y el urbanismo son uno de los elementos esenciales de la vida en sociedad»; «puras y racionales, tales son las formas de las ciudades contemporáneas», que proclamaba Le Corbusier en I934.

La «provincia sitiada» que heredan los arquitectos del siglo XIX como ciudad, debería, ahora, enfrentarse a mediados del siglo XX con el caos de las corrientes demográficas y el magma inmobiliario que colonizaban las sociedades del consumo inducido sobre la ciudad. La Escuela, nos narra la crónica del libro, se debatía en la dialéctica, siempre subordinada y difusa, que lleva consigo construir la arquitectura de la ciudad y cómo diferenciar lo simbólico de lo productivo en el contexto de su tiempo. La estrategia del proyecto escolar recurría a estetizar el objeto arquitectónico, prerrogativa ya asumida por las «corrientes posmodernas» que anunciaban la epifanía del nuevo orden.

La Escuela de Sevilla suficientemente consolidada, acariciaba la búsqueda de arquetipos, sus mitos y tendencias, Italia, Portugal..., y de nuevo se impulsaban en sus aulas las narraciones mitificadoras del proyecto para la ciudad. Experiencias y desengaños no les faltaron a alumnos y profesores al tener que contemplar con desencanto el poder de la impostura en muchos de sus modelos, como ocurrió en aquella «isla de los prodigios» que levantaron los decorados de la Expo 92 en la ciudad. Cuantos interrogantes suscita la relación de estos «monasterios-escuelas de arquitectura» de las universidades contemporáneas y su escasa beligerancia crítica e innovadora en la construcción de la ciudad de nuestro tiempo, o tal vez estamos equivocados y los afanes de la arquitectura ya no residen en construir la morada de los grupos humanos y transformarla. 
Así, la crónica que nos ofrece el libro responde, como ya he señalado, a una lectura de acontecimientos universitarios pormenorizados en sus accidentes pedagógicos, académicos y políticos que sin duda reflejan, en lo familiar de su exposición narrativa, cómo se edifica la realidad urbana acotada más allá del entorno sevillano, reflejo sin duda del acontecer metropolitano a partir de la década de los setenta. Pero, recordando el sabio consejo de Píndaro que parece desprenderse de su lectura «los días por venir son los más sabios testigos de la verdad»s.

La enseñanza de la arquitectura que se manifiesta gráfica y conceptualmente en las aulas, continuaba y sigue desarrollándose como una secuencia de rasgos idealistas de una forma presionada por la función, pero advirtiendo que este proceder pedagógico se enfrenta a un nuevo hecho significativo: el espacio arquitectónico, en los tiempos que aquí comento, ha dejado de ser vacío, mecánico y abstracto, para ser modelado por las nuevas facultades virtuales del sujeto, entre las más sugerentes aquellas que se alimentan de la "memoria instantánea», de un remedo de imágenes virtuales y reales, que tienden a desplazar los restos compositivos del imaginario euclidiano, en el que se fundamentaba las enseñanzas del Proyecto en las aulas de las viejas escuelas.

Será desde las páginas de la publicación de Periferia y el equipo de profesores de la Escuela sevillana, durante el período de tiempo reducido de esta revista, donde se ampliará el innovador panorama académico surgido en las décadas finales del siglo XX; las tensiones entre la razón constructiva y la polisemia de la forma, las relaciones entre posmodernidad y arbitrariedad formal, que tanto en los últimos proyectos construidos como en sus propuestas conceptuales adquieren un protagonismo elocuente $y$ vienen a ser corolario final que invade tantos programas docentes.

Estas memorias nos hablan del aprendizaje del viejo oficio de los maestros constructores, de las vicisitudes para forjar el conocimiento del «opus» y las leyes que edifican su presencia real; también reflejan la precisa función de la materia, de cómo ennoblecer la materia en sintonía con los recuerdos y cómo acariciar su expresión simbólica desde la mirada. Con una precisa advertencia que destilan las casi de trescientas páginas del libro: 
tanto nos condenan o redimen los lugares que habitamos que llegamos a ser el espacio que construimos.

"Extraño invierno este que abora termina».

¿Se despide el autor, en cordial y nostálgica despedida? No lo creo, han sido cincuenta años; un tiempo como en cualquier época, donde la soledad del conocimiento acosa, la aurora es blanca, la belleza del espacio abstracta y el ocaso, aún, casi sin memoria, y donde un «bosque de acantos» crece sin demora en las riberas del Guadalquivir. 